\title{
サービス付き高齢者向け住宅の住居水準と要介護状態の不適合に関する考察 \\ THE CONSIDERATIONS OF THE MISMATCH BETWEEN THE QUALITY LEVEL OF THE DWELLING UNIT AND THE HEALTH CONDITION OF RESIDENTS IN THE ELDERLY HOUSING WITH SUPPORTIVE SERVICES
}

\author{
三宮基裕*1, 黄 昞峻*2, 鈴木義弘*3 \\ Motohiro SANNOMIYA, Byung joon HWANG and Yoshihiro SUZUKI
}

\begin{abstract}
The aim of this paper is to clarify mismatches between the quality level of the dwelling unit and the health condition of residents in the elderly housing with supportive services (the housing).

Many the housing are shared type is the low-quality dwelling units. Because management bodies had expected residents who stand in need of moderate or severe care move into the housing. However about $40 \%$ of residents living in the shared type are self-support or mild care level. Therefor that there is mismatch in the shared type housing.
\end{abstract}

Keywords : Elderly housing with supportive services, Quality level of the dwelling unit, Health condition, Image of the resident, City size comparison サービス付き高齢者向け住宅，住居水準，要介護状態，入居者像，都市規模

\section{1. はじめに}

\section{1 研究の背景と目的}

2000 年以降、高齢者の居住の安定確保に関する法律や住生活基本 法の制定によって、高齢者等に配慮した住宅の整備が本格的に始ま った。背景には地域包括ケアシステムの推進がある。日常生活圈域 で医療・保健・福祉等のサービスが提供できる地域体制づくりを目 指すもので、生活拠点の基盤として自宅とともに高齢者向け住宅が 位置づけられた 1) 2)。この間に創設された各種の高齢者向け住宅注1) は、2011年度より住まいの機能と生活相談・見守りサービスの機能 を備えた「サービス付き高齢者向け住宅」(以下、サ高住）に一本化 注 2)され、国土交通省と厚生労働省が連携して整備を進めている。 子世帯同居から単身・夫婦のみの世帯構成へと変化するなかで、高 齢期の不安は心身機能の低下だけでなく災害や防犯、経済面など多 岐にわたる。少高住は高齢期を迎えた団塊の世代にとって日常生活 に不安を感じる早い時期からの住まいの選択肢となるだろう注 3)。

サ高住には、状況把握・生活相談サービスの提供と、居住者の専 用部分 (以下、住戸) における $25 \mathrm{~m}^{2}$ 以上の面積の確保およびキッ チン・浴室・トイレ等の設備設置の空間要件が定められ、空間要件 には共用設備での代替による住戸面積の緩和規定も付記されている。 サ高住の入居対象は幅が広く、多様な空間・提供サービスの形態が 考えられるが、地域で求められている明確な形態が定められていな いなかで、これらの要件と想定する入居者像を照らし合わせて、事 業者の裁量によって形態が決められていると考えられる。
2017 年 2 月現在、 6,592 棟 215 千戸余りが登録され急速に整備が 進んでいるが、約 6 割が緩和規定を適用した住戸であるというデー タもあり ${ }^{3)}$ 、事業者がじのような入居者を想定して空間・提供サー ビスを考え、それらが実際の居住者の状態に適合しているのか検証 が必要である。また、地域単位での供給促進が課題として指摘 ${ }^{4)} さ$ れるなかで、どのような形態のサ高住が市町村レベルで整備されて いるのかの把握も必要ではないだろうか。

本研究は、サ高住の基本的な空間要素として住居水準注 4) と空間 構成を取り上げ、住居水準および空間構成・提供サービスの形態の 二側面から、実際の居住者の要介護状態注 5) との不適合の実態を明 らかにし、空間の質的改善に資する知見を得ることを第一義的な目 的とし、加えて都市規模の点から整備の特徴を把握することで地域 単位での整備課題を明らかにする。

なお、本論文は既報 ${ }^{5)}$ 6) を加筆・再編したものである。

\section{2 既往研究と本研究の位置づけ}

特別養護老人ホームをはじめとする福祉施設に比べて高齢者向け 住宅の研究、とりわけ制度制定から間もないサ高住を対象とした研 究は萌芽段階である。

建築空間に関わる研究として、永浜ら ${ }^{7)}$ は、住戸の間取りと面積 的特徵、共用設備の設置傾向について平面構成の分析をしている。 山口 ${ }^{8)}$ は、住戸の計画と空間構成の観点から「住宅」としてのサ高 住のあり方を言及し、高齢期の特性を踏まえたうえで幅広い対象に 対応する建築計画の必要性を指摘している。三浦ら ${ }^{9)}$ は、自治体独

\footnotetext{
*1 九州保健福祉大学社会福祉学部臨床福祉学科 准教授 - 修士 (工学)

*2 大分大学工学部 非常勤講師・博士 (工学)

*3 大分大学工学部福祉環境工学科建築コース 教授・博士 (人間環境学)
}

Assoc. Prof., Kyushu Univ. of Health and Welfare, M.Eng.

Part-time lecturer, faculty of Eng., Oita Univ., Dr.Eng.

Prof., faculty of Eng., Oita Univ., Ph.D. 
自の住戸の面積基準の緩和規定に注目し、緩和規定が住戸の質の低 下を招く可能性を示唆している。居住者の生活状況を取り上げた研 究として、山口ら 10) 11) は、住まいと介護の分離による生活の自律 の可能性を検討している。入居要因について山田ら ${ }^{12)}$ は、住宅に 求められるサービスや環境移行の負担軽減のための入居支援のあり 方を考察している。供給ニーズに関する研究として、佐藤ら ${ }^{13)}$ は、

将来推計に基づいて利用可能性のある高齢者数を算定し、必要住宅 数の算出を試みている。さらに井上 ${ }^{14)}$ は、費用負担の観点から自 宅・高齢者住宅・施設を比較分析し、首都圈周縁部または地方中核 市におけるサ高住整備の堅調な実態や住宅・介護事業者の業務提携 実態のメカニズムを考察し、サ高住の質的課題を指摘している。

本研究に関わる先攻研究として、黄ら ${ }^{15)}$ は、グループホームに おける居室水準の低さが居室のしつらえに制約を与え、その結果、 基本的な行為が共用空間へ移行していることを明らかにしている。

本研究は、多様な形態が考えられるサ高住において、居住者の要 介護状態が空間要素に適合しているかを評価するもので、この視点 から空間改善に資する知見を得ようとする研究はなされていない。

\section{3 研究の枠組み}

まず、登録住戸数、住居水準、空間構成、提供サービスについて 全国的な整備状況の把握をおこなう。地域的な特徵をみる一つの指 標として所在都市の人口規模を分析の視点におく（第 2 章）。

次に、住居水準を踏まえた空間構成の軸とサービスの程度による

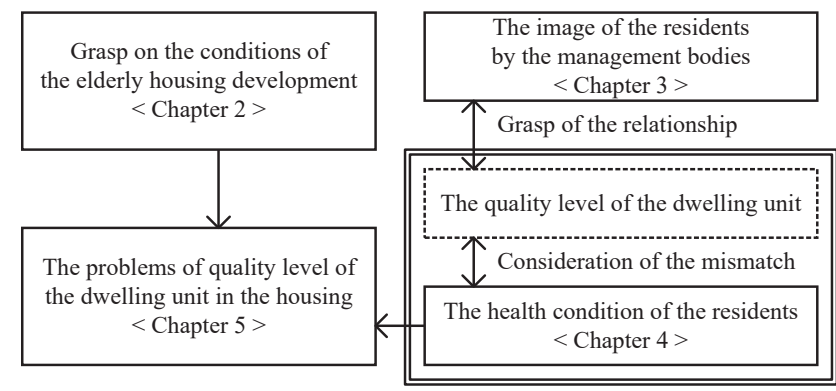

Fig.1 Study scheme

Table1 Outline of the survey

\begin{tabular}{|c|c|}
\hline Survey 1 & Data collection from the information system on the website \\
\hline Method & Access the website https://www.satsuki-jutaku.jp/ \\
\hline Period & The end of March, 2014 to early April, 2014 \\
\hline Target & 3,482 housings: the elderly housing opened by the end of March, 2014 \\
\hline Contents & $\begin{array}{l}\text { The mailing address } \\
\text { The kind of management bodies } \\
\text { The number of dwelling units, the plan types } \\
\text { The common space and equipments } \\
\text { The contents of the support service etc. }\end{array}$ \\
\hline Survey 2 & Individual research targeting to the elderly housing \\
\hline Method & Mail surveys by the questionnaire \\
\hline Period & First time :December, 2014 Second time :July, 2016 \\
\hline Response & $\begin{array}{l}\text { 1st : } 145 / 1,000 \text { 2nd }: 472 / 2,482 \text { Total }: 617 / 3,482 \\
\text { Response rate: } 18.7 \%\end{array}$ \\
\hline Contents & $\begin{array}{l}\text { The residents attribute } \\
\text { - Age, Sex, Degree of needed care etc. } \\
\text { The image of the residents by the management bodies } \\
\text { - Health condition } \\
\text { - Households } \\
\text { - Income etc. } \\
\text { The considerations for the floor plan } \\
\text { - The area of dwelling unit } \\
\text { - The common space and equipments } \\
\text { - The purpose of the elderly housing in the community etc. } \\
\text { The common space usage } \\
\text { - The number of user } \\
\text { - Activities } \\
\text { - Usage frequency of the space etc. }\end{array}$ \\
\hline
\end{tabular}

提供サービスの軸を設定し、第 3 章では事業者が想定する入居者像 （世帯規模や要介護状態など）と分析軸との関係から設置の考え方 を解釈し、そのうえで、第 4 章では実際の居住者の要介護状態と分 析軸とを関係づけて考察し不適合の実態を探る。

以上の分析結果を踏まえて、地域的な特徴の視点も含めてサ高住 の空間課題を知見としてまとめる（第 5 章）（Fig.1）。

\section{4 調査概要}

調查の概要を Table1 に示す。調查 1 (Survey 1) として一般社団 法人高齢者住宅推進機構が WEB で管理する『サービス付き高齢者 向け住宅情報提供システム』を用いて、入居開始日が 2014 年 3 月 末日までの 3,482 カ所の登録情報を収集した注6)。システムへのアク セス期間は 2014 年 3 月末〜 4 月上旬である。

調査 2 (Survey 2) として 3,482 カ所すべてを対象に、居住者の 属性、想定した入居者像、住宅の位置づけ、住戸面積、共用設備の 利用などについて郵送によるアンケート調查を実施した。2014 年 12 月に 1,000 力所、 2016 年 7 月に 2,482 力所の 2 度に分けて実施 し、計 617 力所から回答を得た。宛先不明の 68 力所を除く回収率 は $18.7 \%$ である注7)。本論文では宛先不明は未設置とみなし、WEB 情報 3,482 力所から 68 力所を除く 3,414 力所を分析対象とした。

\section{2. サ高住の整備状況 \\ 2.1 都市規模の分類}

全国的な整備状況を把握するにあたり、地域的な特徵を理解する 一つの指標として都市の人口規模を分析軸においた。

家計調查（総務省統計局）の都市階級区分を参考に、人口は 2010 年国勢調查の結果を用いて、以下のように都市規模を設定した注8)。

大都市 (Metropolis) : 東京都区部および 50 万人以上の市

中都市 (City) : 大都市を除く 15 万人以上の市

小都市 (Town) : 1 万人以上 15 万人未満の市町村

町村部（Village）：1 万人未満の町村

\section{2 登録件数と登録戸数}

情報提供システムへの登録件数は（Table2）、小都市（42.0\%）、 中都市 (29.9\%)、大都市 (23.0\%) の順で比率が高く、町村部は 5.1\% とわずかである。

登録戸数も同様に小都市が多いが、1 カ所あたりでは都市規模が 大きくなるにしたがい戸数も多くなっている。65 歳以上人口千人あ たりの登録戸数をみると、中都市が 65 歳以上で 4.43 戸、 75 歳以上 で 9.76 戸と最も多く、借家層が多いと考えられる大都市は中都市よ

Table2 The number of the registrations and the dwelling units

\begin{tabular}{|c|c|c|c|c|c|c|}
\hline & Overall & Metropolis & City & Town & Village \\
\hline \multicolumn{2}{|c|}{$\begin{array}{l}\text { The number of } \\
\text { registrations }(A)\end{array}$} & $\begin{array}{r}3,414 \\
100 \%\end{array}$ & \begin{tabular}{|c|}
785 \\
$23.0 \%$
\end{tabular} & \begin{tabular}{l|}
1,021 \\
$29.9 \%$
\end{tabular} & $\begin{array}{l}1,435 \\
42.0 \%\end{array}$ & $\begin{array}{l}173 \\
5.1 \%\end{array}$ \\
\hline \multicolumn{2}{|c|}{$\begin{array}{l}\text { The number of } \\
\text { dwelling units (B) }\end{array}$} & $\begin{array}{r}107,664 \\
100 \% \\
\end{array}$ & $\begin{array}{r}30,430 \\
28.3 \% \\
\end{array}$ & $\begin{array}{r}31,856 \\
29.6 \% \\
\end{array}$ & $\begin{array}{r}41,492 \\
38.5 \% \\
\end{array}$ & $\begin{array}{r}3,886 \\
3.6 \% \\
\end{array}$ \\
\hline \multicolumn{2}{|r|}{$B / A$} & 31.5 & 38.8 & 31.2 & 28.9 & 22.5 \\
\hline \multirow{3}{*}{$\begin{array}{l}\text { 응 } \\
\text { 융 } \\
\text { 응응 } \\
0\end{array}$} & Total & 128,057 & 36,701 & 33,195 & 50,024 & 8,137 \\
\hline & Over $65(\mathrm{C})$ & $\begin{array}{r}29,246 \\
22.8 \% \\
\end{array}$ & $\begin{array}{c}7,480 \\
20.4 \% \\
\end{array}$ & $\begin{array}{c}7,190 \\
21.7 \% \\
\end{array}$ & $\begin{array}{r}11,908 \\
23.8 \% \\
\end{array}$ & $\begin{array}{c}2,667 \\
32.8 \% \\
\end{array}$ \\
\hline & Over 75 (D) & $\begin{array}{c}14,072 \\
11.0 \% \\
\end{array}$ & $\begin{array}{r}3,410 \\
9.3 \% \\
\end{array}$ & $\begin{array}{c}3,265 \\
9.8 \% \\
\end{array}$ & $\begin{array}{l}5,853 \\
11.7 \% \\
\end{array}$ & $\begin{array}{l}1,544 \\
19.0 \% \\
\end{array}$ \\
\hline \multicolumn{2}{|r|}{$B / C$} & 3.68 & 4.07 & 4.43 & 3.48 & 1.46 \\
\hline \multicolumn{2}{|r|}{$B / D$} & 7.65 & 8.92 & 9.76 & 7.09 & 2.52 \\
\hline
\end{tabular}


りも少ない。また、町村部では前者が 1.46 戸、後者が 2.52 戸で他 の都市規模との差が大きい。人口情報だけで過不足の評価はできな いが、都市規模により整備数に差があることが確認できる。

\section{3 住居水準 · 空間構成・提供サービスの特徵}

\subsection{1 住戸タイプの分類}

サ高住の登録基準には住戸内設備の緩和規定があるため、いくつ かの設備設置パターンがある。住戸の特徴をみるために台所・浴室 の有無を基準にして以下のように住戸タイプを整理した ${ }^{16)}$ (Fig.2)。 完備型住戸（Flat type）：専用の台所・浴室を設置 共用型住戸（Room type）：台所・浴室の何れかまたは両方が共用 K 型（Kitchen type）：専用の台所を設置（浴室は共用）

B 型（Bath type）：専用の浴室を設置（台所は共用）

$\mathrm{S}$ 型（Sanitary type）：トイレ・洗面設備のみ設置

（台所・浴室は共用）

\section{3 .2 住居水準}

住居水準として住戸タイプと面積をみた。住戸タイプの構成比率

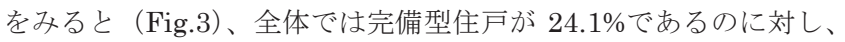
共用型住戸が $75.9 \%$ と圧倒的に多い。共用型住戸は $\mathrm{K}$ 型と $\mathrm{S}$ 型に二 分され共用 $\mathrm{S}$ 型が大半を占めている。都市規模により構成比率に違 いがみられる。大都市では完備型住戸 (34.9\%) と共用 K 型 (18.9\%) で半数以上を占め、中都市でも同様の傾向を示す。一方、小都市と 町村部では共用 $\mathrm{S}$ 型の比率が 6 割を超え、とくに町村部では $82.2 \%$ を占め、都市部に比べて住戸タイプが偏在している。

住戸タイプ別の面積注9) をみると (Table3)、完備型住戸は平均值 $36.0 \mathrm{~m}^{2}$ であるがばらつきが大きく、中央值は $25.8 \mathrm{~m}^{2}$ で単身の最低 居住面積水準程度である。大都市のばらつきはとくに大きく多様な 広さの住戸が存在していることがわかる。共用型住戸の平均值は 20 〜 $25 \mathrm{~m}^{2}$ であるが同様にばらつきがあり、中央值は $\mathrm{K}$ 型 $19.0 \mathrm{~m}^{2} 、 \mathrm{~B}$ 型 $22.7 \mathrm{~m}^{2} 、 \mathrm{~S}$ 型 $18.4 \mathrm{~m}^{2}$ である。とくに $\mathrm{K}$ 型と $\mathrm{S}$ 型の中央值の差は 小さく台所設備の設置により居室部分が狭められていることが示唆 される。都市規模ごとに中央值をみると、都市規模間の差は僅かで あるがどの住戸タイプも町村部はやや広い傾向にある。

\begin{tabular}{|c|c|c|c|c|c|}
\hline \multicolumn{4}{|c|}{ Dwelling unit types } & \multicolumn{2}{|c|}{ Explanatory notes } \\
\hline \multirow{2}{*}{ Flat type } & \multicolumn{3}{|c|}{ Room type } & \multirow{2}{*}{$\begin{array}{l}\text { Personal } \\
\text { space }\end{array}$} & \multirow{2}{*}{ Dwelling uni } \\
\hline & Kitchen type & Bath type & Sanitary type & & \\
\hline \begin{tabular}{|l} 
Personal \\
space
\end{tabular} & $\begin{array}{l}\text { Personal } \\
\text { space }\end{array}$ & $\begin{array}{l}\text { Personal } \\
\text { space }\end{array}$ & $\begin{array}{l}\text { Personal } \\
\text { space }\end{array}$ & Sani & $\begin{array}{l}\text { Toilet and } \\
\text { washstand }\end{array}$ \\
\hline (K) $\frac{B}{\text { Sani }}$ & (K) Sani & Bani & Sani & & $\begin{array}{l}\text { Kitchen } \\
\text { Bath room }\end{array}$ \\
\hline
\end{tabular}

Fig.2 Dwelling unit types of the housing

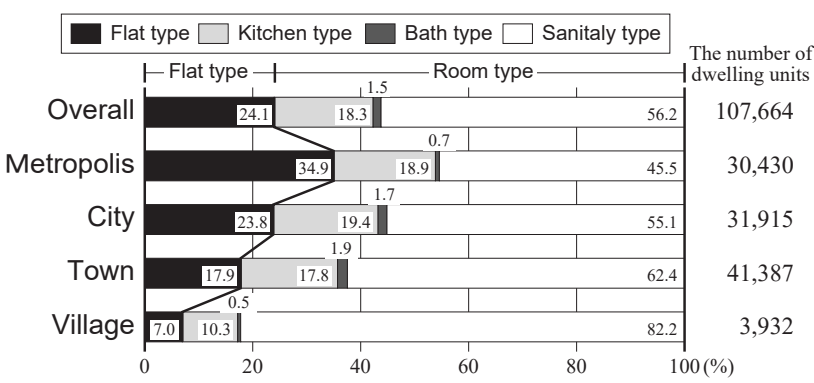

Fig.3 Component ratio of the dwelling unit types

\subsection{3 共用設備の有無}

共用設備として、居間 $(\mathrm{L})$ 、食事室 $(\mathrm{D})$ 、台所 $(\mathrm{K}) 、$ 、イレ、 浴室の有無をみた注 10) (Fig.4)。設置していないのは 3.9\%であり、 $96.1 \%$ がずれかの共用設備を有している。LDK と浴室の設置率が 高く、とくに 95.6\%が LDK のいずれかを設けている。

\subsection{4 空間構成}

サ高住の基本的な空間構成を理解するために、住戸タイプと共用 設備の有無により以下のように分類した注 11) 17) (Fig.5)。

アパート型 $(\mathrm{Ap})$ :

各住戸で生活が完結し、居住者同士で利用する共用設備は有 さない空間構成。一般の共同住宅のような形態。

コレクティブ型 $(\mathrm{Co})$ :

各住戸で生活が完結しつつ、居住者同士で利用寸る共用設備 を有し、必要に応じて生活を共用設備に依存できる空間構成。 コレクティブハウスのような形態。

シェアード型（Sh）：

各住戸でキッチンまたは浴室が久け、生活の一部または全部 を共用設備に依存する空間構成。シェアハウスのような形態。 コレクティブ+シェアード型（Co+Sh）:

完備型と共用型住戸が混在し、共用設備を有する空間構成。

この分類で空間構成の構成比率をみると（Fig.6）、Sh が $69.0 \%$ 空間構成の大半を占めている。Co は $16.3 \%$ 、共同住宅に近い Ap は $3.9 \%$ とわずかであるが、大都市では Ap・Co が 3 割ある。都市規模 が小さくなるとともに Sh の比率が高くなり、町村部では $84.4 \% を$ 占める。Co+Sh はそれぞれの都市規模で 1 割程度存在する。

Table3 Floor area of the dwelling units

\begin{tabular}{|c|c|c|c|c|c|c|c|c|}
\hline \multirow{4}{*}{ Overall } & \multirow{2}{*}{\multicolumn{2}{|c|}{ Flat type }} & \multicolumn{6}{|c|}{ Room type } \\
\hline & & & \multicolumn{2}{|c|}{ Kitchen type } & \multicolumn{2}{|c|}{ Bath type } & \multicolumn{2}{|c|}{ Sanitary type } \\
\hline & 18.0 & $36.0(13.0)$ & 16.6 & $23.1(5.9)$ & 18.0 & $25.9(5.6)$ & 13.9 & 20.1 \\
\hline & 162.9 & $25.8[7.0]$ & 64.2 & $19.0[3.0]$ & 52.2 & $22.7[3.8]$ & 62.1 & $18.4[1.3]$ \\
\hline \multirow{2}{*}{$\begin{array}{c}\text { Metro- } \\
\text { polis }\end{array}$} & 18.0 & $37.8(14.9)$ & 16.6 & $23.8(7.1)$ & 18.1 & $25.1(5.2)$ & 13.9 & $20.0(3.4)$ \\
\hline & 162.9 & 25.5 [5.9] & 64.2 & $19.2[3.0]$ & 43.2 & $24.6[2.1]$ & 49.0 & $18.3[1.0]$ \\
\hline \multirow{2}{*}{ City } & 18.2 & $34.0(10.7)$ & 18.0 & $22.6(5.1)$ & 18.3 & $25.2(4.6)$ & 18.0 & $19.9(3.0)$ \\
\hline & 78.9 & $25.6[6.9]$ & 56.1 & $18.7[2.5]$ & 45.1 & $22.7[1.1]$ & 45.5 & $18.4[1.4]$ \\
\hline \multirow{2}{*}{ Town } & 18.3 & $35.2(11.5)$ & 18.0 & $23.1(5.4)$ & 18.0 & $26.3(6.2)$ & 18.0 & $20.3(3.4)$ \\
\hline & 97.0 & $26.5[9.2]$ & 57.5 & $18.9[3.4]$ & 52.2 & $22.4[3.2]$ & 62.1 & $18.4[1.4]$ \\
\hline \multirow{2}{*}{ Village } & 22.8 & $30.9(5.3)$ & 18.0 & $22.8(5.5)$ & 20.6 & $27.3(5.9)$ & 18.0 & 20.5 \\
\hline & 51.3 & $27.5[2.8]$ & 43.3 & $22.4[6.1]$ & 42.1 & $25.1[3.0]$ & 36.6 & $18.3[1.5]$ \\
\hline
\end{tabular}

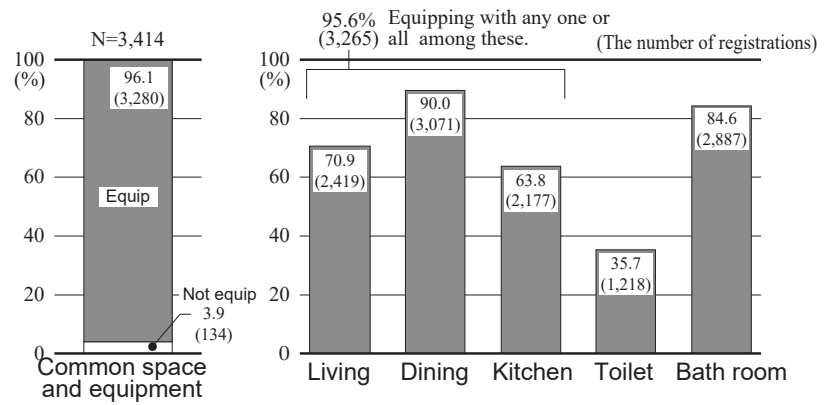

Fig.4 Common space and equipment in the housing 


\subsection{5 提供サービス}

サ高住では状況把握・生活相談を必須サービスとし、その他の少 ービスは事業者によりさまざまである。情報提供システムの共通入 力事項であるサービスの種類「状況把握・生活相談 (Consultation)」

「食事の提供（Meal）」「調理等の家事（Housework）」「入浴等の 介護（Care）」について、提供の組合せをみた注 ${ }^{12 ）}$ (Table4)。

相談から介護まですべてのサービスを提供する組合せが $46.5 \%$ で

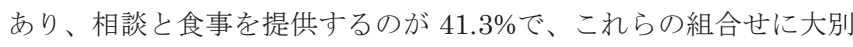
される。家事または介護を提供している住宅のうち、食事を提供し ていない 12 カ所は、レストランの併設や他事業者との別契約をと る形態をとっていた。また、家事を提供しない相談・食事・介護の 組合せの 90 カ所のうち 18 カ所はその他のサービスの中に家事に関 わる援助を含んでいた。

以上の結果を踏まえて、松川ら ${ }^{16)}$ による生活支援類型およびそ の元となっている文献 ${ }^{18)}$ を参考に提供サービスを分類した注 ${ }^{13)}$ 。

相談支援 (CS) : 生活相談を基本としたサービスの提供 自立から要介護 1 程度までに対応

食事提供（MO）：生活相談に加えて食事サービスを提供 要支援 1 から要介護 1 程度までに対応

家事援助（HS）: 家庭機能の代替的な援助までのサービスを提供 要介護 2 から要介護 3 程度までに対応

生活介護（PC）：日常生活動作の介護までのサービスを提供 要介護 4 から要介護 5 までに対応

都市規模による特徵をみると（Fig.7）、大都市では MO が $50.4 \%$ で CS を含めると約 6 割となり、食事提供程度の住宅と介護までを 提供する住宅に二分される。都市規模が小さくなるに従い MO の比

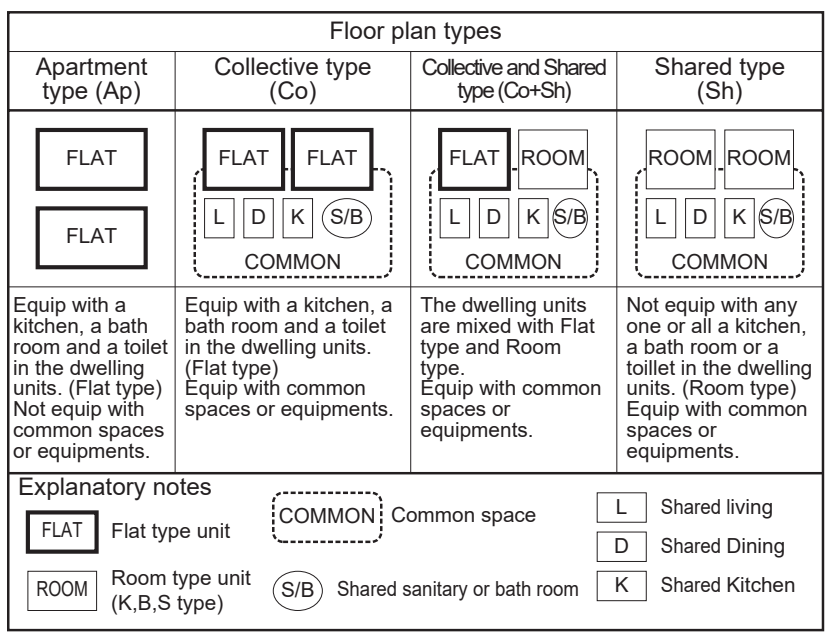

Fig.5 Classification of the floor plan types

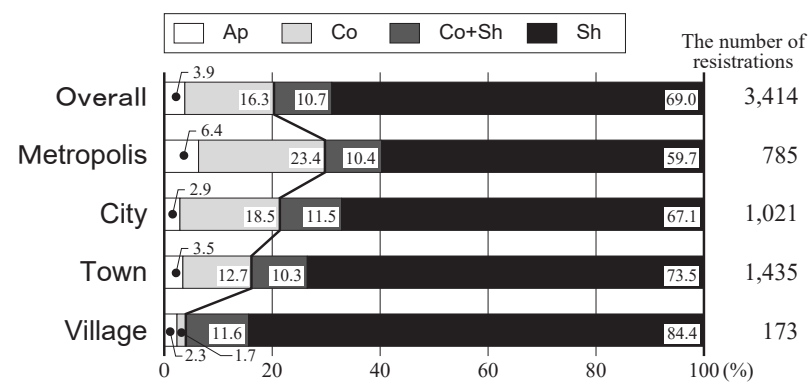

Fig.6 Component ratio of the floor plan types
率が減る一方で PC が高くなり、町村部では PC が $64.2 \%$ 占め介 護までを提供する住宅が中心となっている。

\section{3. 事業者の想定する入居者像 \\ 3.1 分析対象と分析軸}

この章では事業者に対しておこなったアンケート調查（調査 2) の結果を用いて想定した入居者像の分析をおこなう。分析対象は 617 力所である。分析にあたって、空間構成の分類（2.3.4）および 提供サービスの分類（2.3.5）を用い、住戸の住居水準と提供される サービスの程度を考慮して、以下の分析軸を設定した。（Fig.8）。

住戸・自活型住宅（F-S : Flat and Self-support）

空間構成が $\mathrm{Ap} ・ \mathrm{Co}$ で提供サービスが $\mathrm{CS} ・ \mathrm{MO}$ の住宅 生活の独立性が高い完備型住戸で、食事提供程度のサービス を提供。単身・夫婦等の入居、自立・軽度に対応

住戸・援助型住宅 (F-A : Flat and Assistance) 空間構成が $\mathrm{Ap} ・ \mathrm{Co}$ で提供サービスが $\mathrm{HS}$ ・PC の住宅 生活の独立性が高い完備型住戸で、家事・介護等のサービス を提供。単身・夫婦等の入居、中・重度まで対応

居室・自活型住宅 (R-S : Room and Self-support) 空間構成が Sh で提供サービスが CS・MO の住宅 生活の一部または全部を共用設備に依存する共用型住戸で、 食事提供程度のサービスを提供。単身、自立・軽度に対応 居室・援助型住宅（R-A : Room and Assistance）

空間構成が Sh で提供サービスが HS・PC の住宅

生活の一部または全部を共用設備に依存する共用型住戸で、 家事・介護等のサービスを提供。単身、中・重度まで対応

混合・自活型住宅 (FR-S : Flat+Room and Self-support) 空間構成が $\mathrm{Co}+\mathrm{Sh}$ で提供サービスが CS・MO の住宅 完備型と共用型住戸が混在し、食事提供程度のサービスを提 供。単身・夫婦等の入居、自立・軽度に対応

Table4 Support service types

\begin{tabular}{|c|c|c|c|c|c|c|c|}
\hline & \begin{tabular}{|c|}
$\begin{array}{c}\text { Consul- } \\
\text { tation }\end{array}$ \\
\end{tabular} & Meal & \begin{tabular}{|c|} 
House- \\
work
\end{tabular} & Care & \begin{tabular}{|l|} 
The number of \\
registrations $(\%)$
\end{tabular} & & Support type \\
\hline \multirow{7}{*}{ 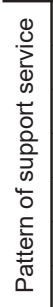 } & 0 & $x$ & $x$ & $x$ & $142 \quad(4.2)$ & C S & $\begin{array}{l}\text { Only provide the } \\
\text { consultation services }\end{array}$ \\
\hline & 0 & 0 & $x$ & $x$ & $1,409(41.3)$ & M O & $\begin{array}{l}\text { Provide the consultation and } \\
\text { the meal offering services }\end{array}$ \\
\hline & O & O & O & $x$ & $172(5.0)$ & \multirow{2}{*}{$\mathrm{HS}$} & \multirow{2}{*}{$\begin{array}{l}\text { Provide the housework } \\
\text { support services }\end{array}$} \\
\hline & O & $x$ & O & $x$ & $4(0.1)$ & & \\
\hline & O & $x$ & O & O & $\begin{array}{ll}8 & (0.2)\end{array}$ & \multirow{3}{*}{$P C$} & \multirow{3}{*}{$\begin{array}{l}\text { Provide the personal care } \\
\text { services }\end{array}$} \\
\hline & 0 & O & $x$ & O & $\begin{array}{ll}90 & (2.6)\end{array}$ & & \\
\hline & O & 0 & O & O & $1,589(46.5)$ & & \\
\hline Total & \begin{tabular}{|l|}
3,414 \\
$(100)$ \\
\end{tabular} & \begin{tabular}{|l|}
3,260 \\
$(95.5)$ \\
\end{tabular} & \begin{tabular}{|l|}
1,773 \\
$(51.9)$ \\
\end{tabular} & $\begin{array}{l}1,687 \\
(49.4) \\
\end{array}$ & \begin{tabular}{|l}
$3,414(100)$ \\
$(100)$
\end{tabular} & \multicolumn{2}{|c|}{$\begin{array}{l}\text { O: Provide } \times \text { : Not provide } \\
\text { Meal: Meal offering or catering } \\
\text { Care: Personal care of ADL }\end{array}$} \\
\hline
\end{tabular}

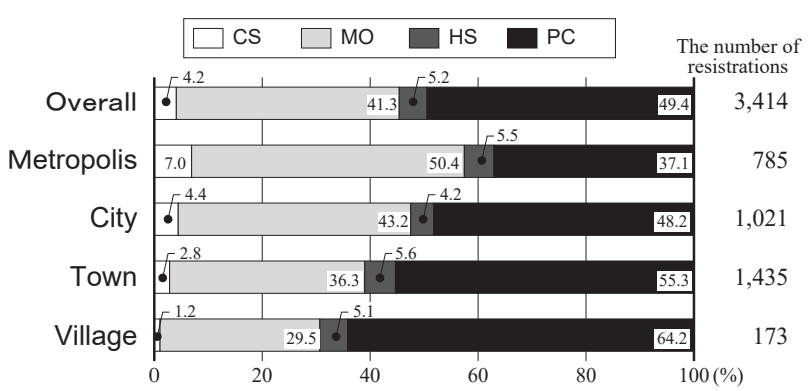

Fig.7 Component ratio of the support services types 
混合・援助型住宅（FR-A：Flat+Room and assistance） 空間構成が $\mathrm{Co}+\mathrm{Sh}$ で提供サービスが $\mathrm{HS}$ ・PC の住宅 完備型と共用型住戸が混在し、家事・介護等のサービスを提 供。単身・夫婦等の入居、中・重度まで対応

(なお、以降の分析で空間構成のみを分析軸とするときは、「F住宅」 $「 \mathrm{R}$ 住宅」「FR 住宅」と呼称する)

FR 住宅における住戸タイプの組合せは Table5 のとおりである。 完備型十共用 $\mathrm{S}$ 型が 41 力所 $(56.9 \%)$ 、完備型十共用 $\mathrm{K}$ 型が 22 力 所 $(30.6 \%)$ でこれらが基本の組合せである。完備型住戸の設置率 (完備型住戸数 / 全住戸数) をみると、設置率 $25 \%$ 未満の住宅が完 備型十共用 $\mathrm{K}$ 型では $54.5 \%$ 、完備型十共用 $\mathrm{S}$ 型では $75.6 \%$ を占め、 FR 住宅であっても共用型住戸が中心の住戸構成である。

\section{2 世帯規模}

想定した世帯規模は（Table6）、「単身のみ」が $35.2 \%$ 「夫婦等 の複数での入居 (以下、夫婦等)」は $64.8 \%$ であった。提供サービ スによる差はなく空間構成により特徵が認められる。FR 住宅では 8

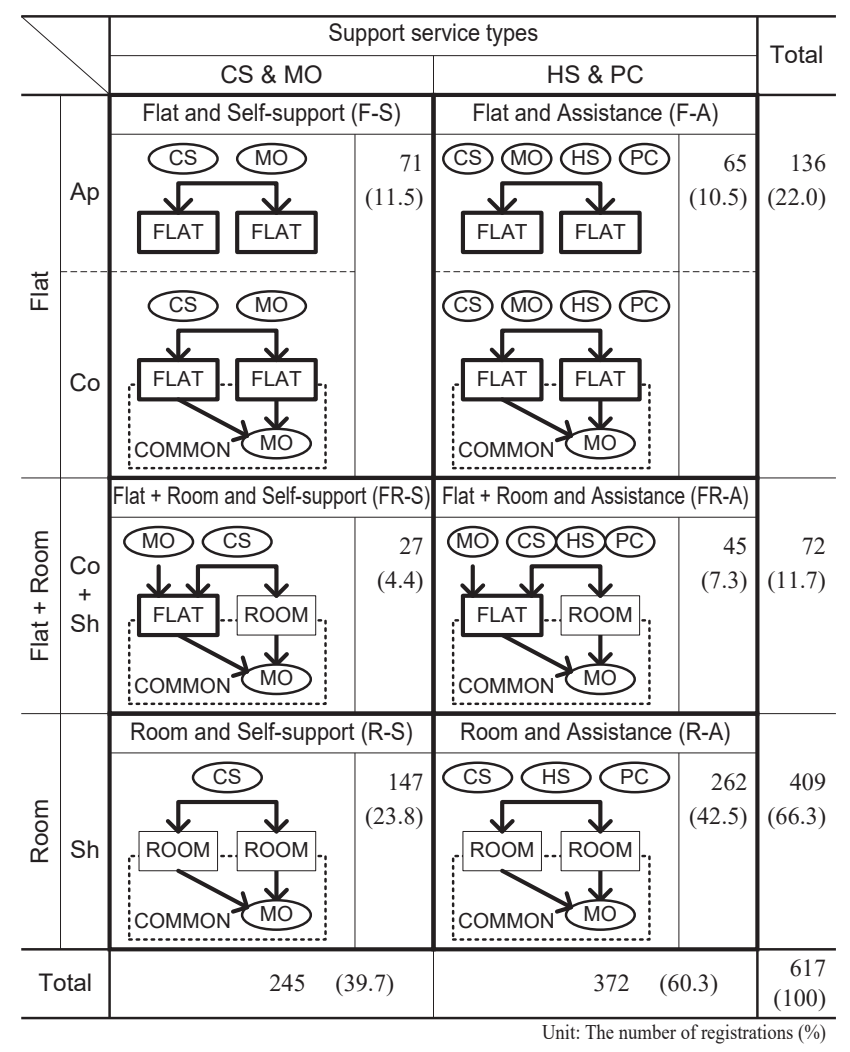

Fig.8 Classification by the floor plan types and the support service types

Table5 Combination of the dwelling unit types, and the flat type ratio

\begin{tabular}{|c|c|c|c|c|c|c|}
\hline & \multirow[b]{2}{*}{ Total } & \multicolumn{4}{|c|}{ Flat type ratio ${ }^{\dagger}$} \\
\hline & & & \begin{tabular}{|} 
Less than \\
$25 \%$
\end{tabular} & $25 \% \sim$ & $50 \% \sim$ & $75 \% \sim$ \\
\hline \multirow{5}{*}{ 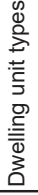 } & Flat+Room(K) & $22(100)$ & $12(54.5)$ & $4(18.2)$ & $3(13.6)$ & $3(13.6)$ \\
\hline & Flat+Room(B) & $1(100)$ & $\begin{array}{ll}0 & (0.0)\end{array}$ & $1(100.0)$ & $\begin{array}{ll}0 & (0.0)\end{array}$ & $\begin{array}{ll}0 & (0.0)\end{array}$ \\
\hline & Flat+Room(S) & $41(100)$ & $31 \quad(75.6)$ & \begin{tabular}{|ll}
3 & $(7.3)$ \\
\end{tabular} & $5 \quad(12.2)$ & $\begin{array}{ll}2 & (4.9)\end{array}$ \\
\hline & Flat $+(\mathrm{K})+(\mathrm{S})$ & $7(100)$ & $6(85.7)$ & $1(14.3)$ & $\begin{array}{ll}0 & (0.0) \\
\end{array}$ & $\begin{array}{ll}0 & (0.0) \\
\end{array}$ \\
\hline & Flat $+(\mathrm{K})+(\mathrm{B})+(\mathrm{S})$ & $1(100)$ & $1(100.0)$ & $\begin{array}{ll}0 & (0.0) \\
\end{array}$ & $\begin{array}{ll}0 & (0.0) \\
\end{array}$ & $\begin{array}{ll}0 & (0.0) \\
\end{array}$ \\
\hline \multicolumn{2}{|c|}{ Overall } & $72(100)$ & $50(69.4)$ & $9(12.5)$ & $8(11.1)$ & $\begin{array}{ll}5 & (6.9)\end{array}$ \\
\hline
\end{tabular}

Unit: The number of the registrations (\%)

† Flat type ratio $=$ The number of the flat types $/$ The number of the dewlling unit types
割以上、 $\mathrm{F}$ 住宅では 7 割が夫婦等の入居を想定している。一方、 $\mathrm{R}$ 住宅では単身のみが他よりも高い傾向にあるが、夫婦等の入居も想 定した住宅が 6 割存在する。 $\mathrm{F}$ 住宅の住戸はす心゙て完備型住戸であ り、FR 住宅も一部が完備型住戸であるので夫婦の同室入居にも対 応できると考えられる。しかし $\mathrm{R}$ 住宅の住戸はすべて共用型住戸で あるため、夫婦等の同室入居に対応しているとは言い難い。

実際の単身入居率をみた（Fig.9）。単身のみを想定した住宅では F-S と F-A はほぼ $100 \%$ でるが、その他は 1 割程度の夫婦等の入 居がある。夫婦等も想定した住宅では何れも 2 割程度夫婦等の入居 がある。実際の居住者においても $\mathrm{R}$ 住宅において夫婦等の入居が確 認でき、世帯規模と住居水準が対応できていないことが示唆される。

\section{3 夫婦等住戸への面積的な配慮}

夫婦等の入居を想定した 370 カ所について、面積拡張の配慮をみ た（Table7）。60.2\%（221 カ所）が「単身よりも広くした」とし、 「全てを広くした」は $15.0 \%$ (55 カ所) で大半が面積的な配慮をし ていた。配慮していな住宅（91 カ所）のうち約 8 割（75 力所）は $\mathrm{R}$ 住宅であった。空間構成・提供サービスとの関係をみると、F-A では「全てを広くした」FR-S と FR-A は「単身よりも広くした」、 R-A では「配慮していない」が特徴的な傾向として読み取れた。空 間構成で合算してた残差分析から F 住宅はすべての住戸、FR 住宅 は一部を広くし、 R 住宅は配慮をしていない傾向が示された。

さらに面積を拡張した 276 力所（一部： 221 力所、全て : 55 力所） について空間構成別に住戸の面積をみた。なお、戸々で面積は異な るので階級を設定し住戸数の多い順に整理した注 ${ }^{14)}$ 。Table8 は上位 2 つの組合せを示したものである。 $\mathrm{F}$ 住宅では、 $25 \mathrm{~m}^{2}$ 以上を基本に して $30 \mathrm{~m}^{2}$ 以上、 $40 \mathrm{~m}^{2}$ 以上との組合せが多い。FR 住宅では $18 \mathrm{~m}^{2}$ 以 上が基本となり $25 \mathrm{~m}^{2}$ 以上、 $30 \mathrm{~m}^{2}$ 以上が代表的である。 $\mathrm{R}$ 住宅では 面積階級 1 種類が最も多くその面積は $18 \mathrm{~m}^{2}$ 以上であり、 $25 \mathrm{~m}^{2}$ 以上、

Table6 Household to be expected by management bodies

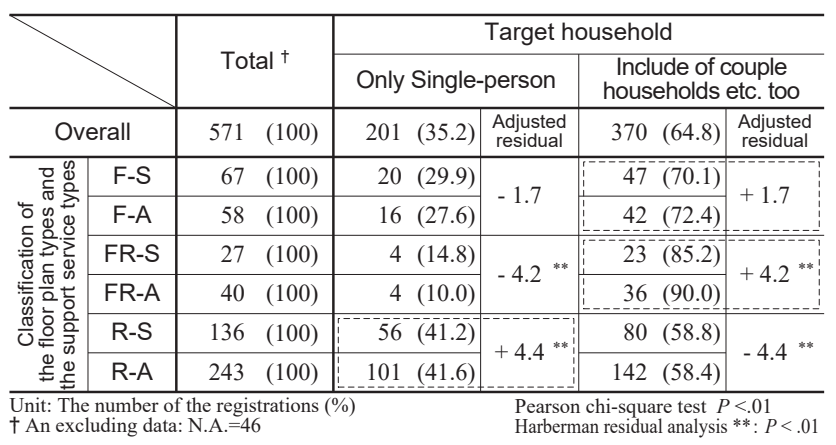

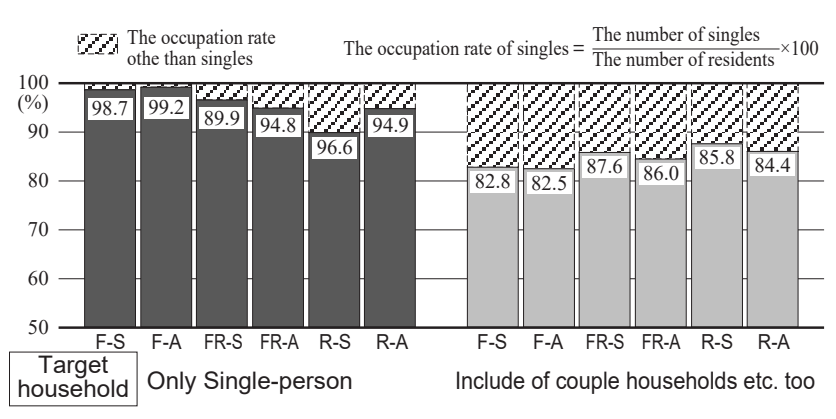

Fig.9 The ratio of the single-person household to the number of registrations 
$30 \mathrm{~m}^{2}$ 以上との組合せが主である。階級度数 2 位の面積階級が夫婦等 に配慮した住戸とすると、 $\mathrm{F}$ 住宅では 2 人用最低居住面積水準、 $\mathrm{R}$ ・ $\mathrm{FR}$ 住宅では単身の最低居住面積水準程度であり、とくに $\mathrm{R}$ 住宅は 拡張の配慮をしても $25 \mathrm{~m}^{2}$ 未満であることから、単身、夫婦等のい ずれの世帯規模の住戸においても最低限の面積水準である。

\section{4 入居を見込んだ要介護状態}

入居を見込んだ要介護状態注 15$)$ を以下の段階で区分した。

見守期（Stage of self-support）：自立から要介護 1 まで

支援期（Stage of support）：自立から要介護 3 まで

介護期（Stage of care）：自立から要介護 5 まで

それぞれの構成比をみると（Table 9$)$ 、介護期 $(40.2 \%)$ 、見守期 (31.5\%)、支援期 $(28.3 \%)$ の順で比率が高いが大差はない。空間 構成・提供サービスとの関係でみると、F-S と F-A はともに見守期 が $46.3 \%$ と $51.7 \%$ で半数を占め、R-S と R-A はいずれも見守期の比 率が低く、支援期と介護期で 7 割以上を占めている。見守り期を想 定する場合では $\mathrm{F}$ 住宅、支援や介護期を想定する場合では R 住宅が 空間構成として採用される傾向が読み取れる。

提供サービスでみると F-S、FR-S では介護期までを想定する住宅 の比率も高くなっており（それぞれ $42.3 \% 、 50.0 \%$ )、提供するサー ビスと想定する要介護状態が対応していない。

\section{5 高齢期の住まいとしてのサ高住の位置づけ}

事業者の考えるサ高住の位置づけは（Fig.10）、「介護の度合いに よらず住み続けられる住まい (Final abode)」が 63.8\%で最も高く、 「要介護期までの一時利用住宅 (Temporary residence)」が 14.1\%、

Table7 Consideration to floor area for households of two or more persons

\begin{tabular}{|c|c|c|c|c|c|c|c|}
\hline \multirow{3}{*}{ Overall } & \multirow{2}{*}{ Total $^{\dagger}$} & \multicolumn{6}{|c|}{ Dwelling units for the couple household etc. } \\
\hline & & \multicolumn{2}{|c|}{ No equipment } & \multicolumn{2}{|c|}{ Part of dwelling units } & \multicolumn{2}{|c|}{ All of dwelling units } \\
\hline & $367(100)$ & 91 (24.8) & \begin{tabular}{|l|} 
Adjusted \\
residual
\end{tabular} & $221(60.2)$ & \begin{tabular}{|l|} 
Adjusted \\
residual
\end{tabular} & $55(15.0)$ & $\begin{array}{l}\text { Adjusted } \\
\text { residual }\end{array}$ \\
\hline F-S & $47 \quad(100)$ & $11(23.4)$ & \multirow{2}{*}{-1.7} & $27(57.4)$ & \multirow{2}{*}{-0.5} & 9 (19.1) & \multirow{2}{*}{$+2.7 *$} \\
\hline F-A & $41 \quad(100)$ & $5^{*}(12.2)$ & & $24(58.5)$ & & $12^{k * *}(29.3)$ & \\
\hline FR-S & $23(100)$ & $0^{* *}(0.0)$ & \multirow{2}{*}{$-4.8^{* *}$} & 20 & \multirow{2}{*}{$+4.5^{* *}$} & $3(13.0)$ & \multirow{2}{*}{-0.3} \\
\hline FR-A & $36 \quad(100)$ & $0^{* * *}(0.0)$ & & $31^{* *(86.1)}$ & & $5(13.9)$ & \\
\hline R-S & $79 \quad(100)$ & 21 (26.6) & \multirow{2}{*}{$+5.0^{* *}$} & $48(60.8)$ & \multirow{2}{*}{$-2.9^{* *}$} & $10(12.7)$ & \multirow{2}{*}{$-2.1^{*}$} \\
\hline R-A & $141(100)$ & $54 *(38.3)$ & & $71^{* *}(50.4)$ & & $16(11.3)$ & \\
\hline
\end{tabular}

Table8 Pattern of the floor area of the dwelling units

\begin{tabular}{|c|c|c|c|c|c|c|c|c|c|}
\hline & & & \multirow{3}{*}{$\frac{\frac{18 \mathrm{~m}^{2} \sim}{6}}{6}$} & of great & est frequ & sency & \multirow{2}{*}{\multicolumn{3}{|c|}{ Total }} \\
\hline & & & & \multirow{2}{*}{$\begin{array}{r}25 \mathrm{~m}^{2} \sim \\
7\end{array}$} & \multirow{2}{*}{$\frac{30 \mathrm{~m}^{2} \sim}{5}$} & \multirow{2}{*}{$\frac{40 m^{2} \sim}{2}$} & & & \\
\hline & \multicolumn{2}{|c|}{ Only one class } & & & & & & 20 & \multirow{5}{*}{72} \\
\hline & \multirow{4}{*}{ 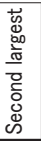 } & $18 m^{2} \sim$ & 0 & 1 & 0 & 0 & 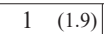 & \multirow{4}{*}{$\begin{array}{r}52 \\
(100)\end{array}$} & \\
\hline$\$$ & & $25 \mathrm{~m}^{2} \sim$ & 1 & 0 & 4 & 0 & $\begin{array}{|ll|}5 & (9.6) \\
\end{array}$ & & \\
\hline & & $30 m^{2} \sim$ & 4 & 17 & 0 & 3 & $24(46.2)$ & & \\
\hline & & $40 m^{2} \sim$ & 0 & 11 & 8 & 3 & $22(42.3)$ & & \\
\hline \multirow{5}{*}{ 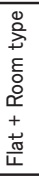 } & \multicolumn{2}{|c|}{ Only one class } & 2 & 1 & 0 & 0 & \multicolumn{2}{|r|}{3} & \multirow{5}{*}{59} \\
\hline & \multirow{4}{*}{ 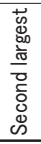 } & $18 m^{2} \sim$ & 0 & 1 & 0 & 0 & $\begin{array}{ll}1 & (1.8) \\
\end{array}$ & \multirow{4}{*}{$\begin{array}{r}56 \\
(100)\end{array}$} & \\
\hline & & $25 m^{2} \sim$ & $\overline{2} 2$ & 0 & 1 & 0 & $23(41.1)$ & & \\
\hline & & $30 \mathrm{~m}^{2} \sim$ & 16 & 7 & 0 & 0 & $23(41.1)$ & & \\
\hline & & $40 m^{2} \sim$ & 4 & 3 & 1 & 1 & $9 \quad(16.1)$ & & \\
\hline \multirow{5}{*}{ 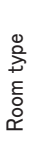 } & \multicolumn{2}{|c|}{ Only one class } & $\overline{5} \bar{i}$ & 1 & 0 & 0 & \multicolumn{2}{|r|}{59} & \multirow{5}{*}{145} \\
\hline & \multirow{4}{*}{ 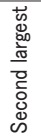 } & $18 m^{2} \sim$ & 0 & 0 & 3 & 0 & 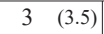 & \multirow{4}{*}{$\begin{array}{r}86 \\
(100)\end{array}$} & \\
\hline & & $25 \mathrm{~m}^{2} \sim$ & $\overline{4}$ & 0 & 2 & 0 & $45 \quad(52.3)$ & & \\
\hline & & $30 m^{2} \sim$ & 30 & 2 & 0 & 0 & $32(37.2)$ & & \\
\hline & & $40 m^{2} \sim$ & 4 & 2 & 0 & 0 & $\begin{array}{ll}6 & (7.0) \\
\end{array}$ & & \\
\hline \multicolumn{7}{|c|}{ Unit: The number of the registrations (\%) } & & & 276 \\
\hline
\end{tabular}

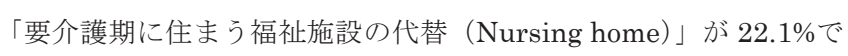
あった。空間構成・提供サービスとの間に有意差は認められなかっ たが、想定する要介護状態との間で $0.1 \%$ の有意水準で差が認められ た。残差分析から見守期では一時利用住宅、支援期は福祉施設、介 護期は住み続けられる住宅が多い傾向にあった。前節 3.4 において $\mathrm{R}$ 住宅が支援・介護期を想定する傾向があったことを踏まえると、 サ高住を終の棲家としたとき、介護が必要となる時期の生活状況を イメージした住居水準にしていると推察される。

\section{4. 居住者の要介護状態と空間構成・提供サービスの適合状況 4.1 介護程度による住宅の類型化}

この章では調查 2 の結果を用いて実際の居住者の要介護状態と空 間構成・提供サービスとの関係を分析する。空間・サービスの分析 軸は前節 3.1 の軸を用いた。要介護状態の分析軸の設定するために、 まず、要介護度に応じて「自立・軽度（Self-support/Mild）：自立 から要介護 $1 」 「 中$ 程度 (Moderate) : 要介護 $2 \cdot 3$ 」「重度 (Sever)： 要介護 $4 \cdot 5$ 」に介護の度合い（以下、介護程度）を区分し、各住 宅における居住者の介護程度の構成比率を算出して、これを変量に して Ward 法による階層クラスター分析をおこなった注 ${ }^{16)}$ 。その結 果、居住者の介護程度が特徴的な 4 グループが抽出できた (Fig.11)。 介護程度の構成比率から、以下のように特徵づけられる。

CLU1：主に自立・軽度者が生活する住宅群

CLU2：自立・軽度者を中心に中程度者が混在する住宅群

CLU3：中程度者が中心に自立・軽度が混在する住宅群

CLU4 : 主に中程度・重度者が生活する住宅群

Table9 Health condition of residents to be expected by management bodies

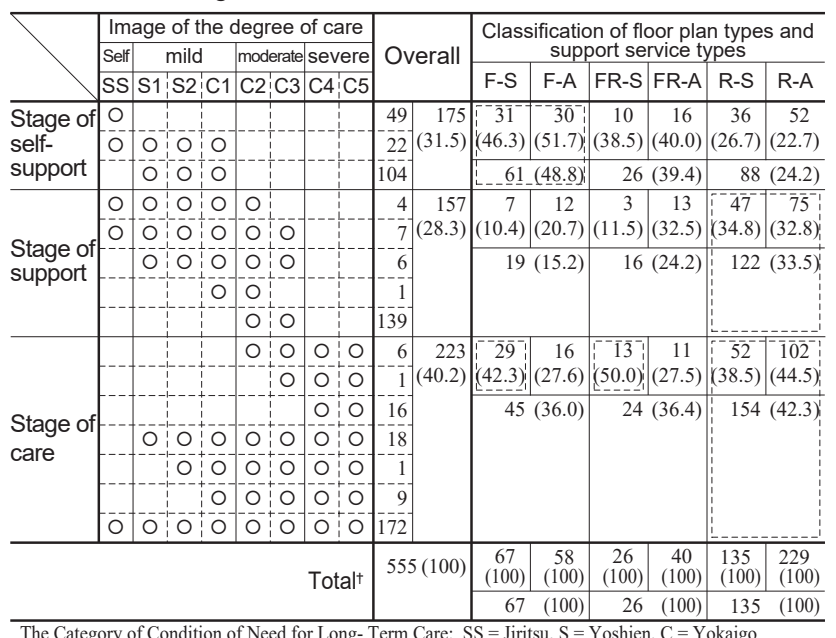

The An excluding data: Other than these response or N.A. $=62$

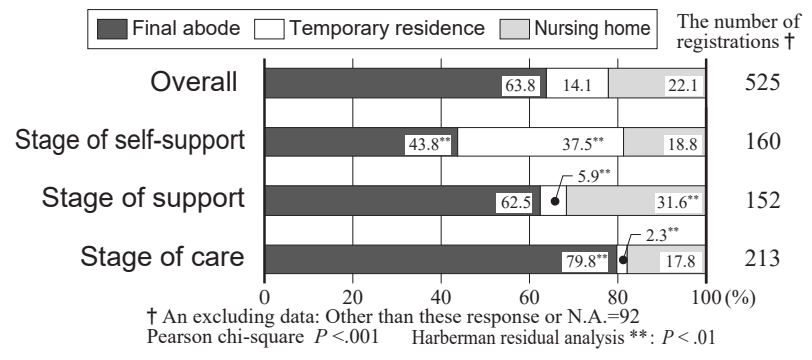

Fig.10 Position in the kind of elderly housing 


\section{2 都市規模による居住者の介護程度の違い}

都市規模ごとに 4 グループの構成比率をみると（Fig.12 左）、大 都市では CLU2 が 44.9\%、CLU1 が 19.5\%で自立度の高い住宅群が 6 割以上を占めている。中都市では $\mathrm{CLU} 3 \cdot 4$ で $60.1 \%$ を占め、中 程度・重度者が中心に生活する住宅群が半数を超えている。町村部 ではCLU1 と CLU3の比率がやや高いが総数が少ないことを考える と大きな差ではなく、いろいろなタイプの住宅が存在している。

居住者の介護程度の構成比率（平均）をみると（Fig.12 右）、い ずれも半数程度が自立・軽度者であり、町村部は大都市の構成比率 に近く、都市規模の小さい地域において介護程度の重い居住者が多 く存在しているわけではない。

\section{3 介護程度のクラスターと空間構成・提供サービスとの関係}

空間構成・提供サービス別に 4 グループの構成比率をみた (Fig.13

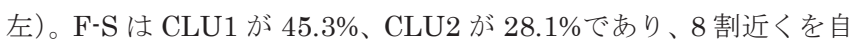
立・軽度者が中心の住宅群で占めている。F-A も同様に CLU1 と CLU2 の比率が高いがこちらは CLU2 の比率の方が高く、F-S に比 べて介護程度がやや重い住宅群で構成されている。FR-S と FR-A も $\mathrm{F}$ 住宅と同様、CLU1 と CLU2 で 7 割を占めるが、ともに CLU2 の比率が高く軽度者が居住する住宅群で構成されている。 R-S と R-A は、CLU2・CLU3・CLU4 が同程度で構成され、軽度中心、 中程度中心、中・重度中心の多様な住宅群が含まれている。

空間構成別に介護程度の構成比率をみると（Fig.13 右）、自立・ 軽度者が $\mathrm{F}$ 住宅では約 6 割、FR 住宅では半数、 $\mathrm{R}$ 住宅においても 約 4 割を占めている。FR 住宅は主に共用型住戸で構成されており (Table.5 参照)、 R 住宅はすべてが共用型住戸である。いずれの住 宅も半数近くは自立・軽度者であり、比較的自立度の高い居住者が 共用型住戸で生活している状況が確認できる。

\section{5. まとめ}

本論文では、サ高住における都市規模ごとでの住居水準・空間構 成・提供サービスの偏在状況および実際の居住者の状況と空間構成

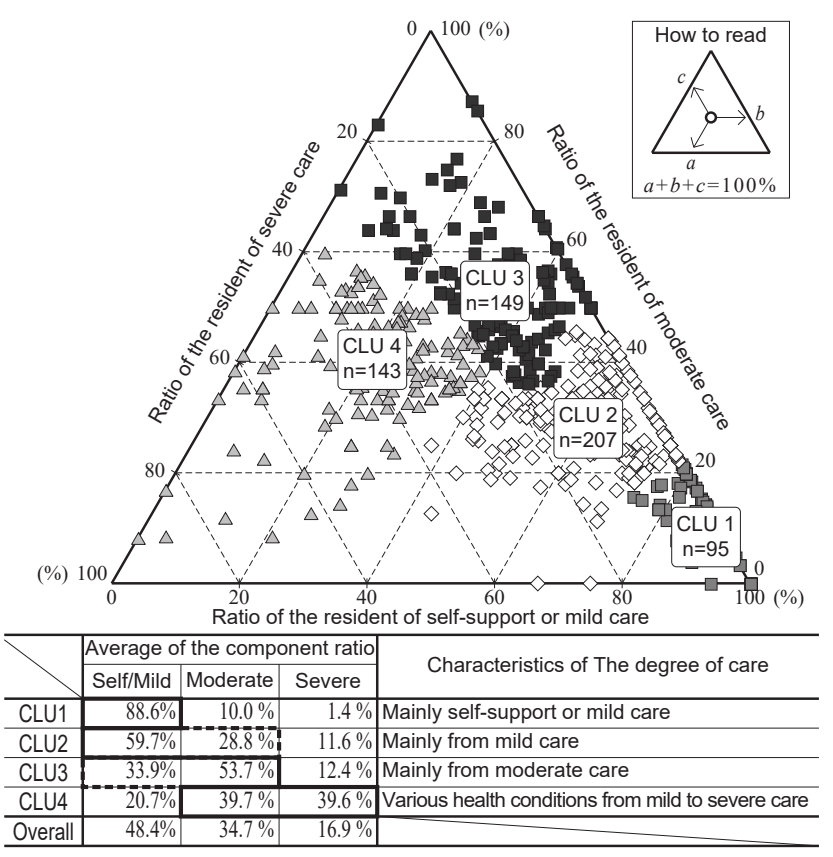

Fig.11 Cluster analysis with the degree of care
との間の不適合の実態を客観的データにより明らかにした。

都市規模ごとの偏在では町村部の整備状況が問題として指摘でき る。町村部では、共用型住戸で構成されるシェアード型の空間構成 で介護サービスまでを提供する住宅が大半を占めるが、都市規模が 大きくなるに従い完備型住戸を備えたコレクティブ型の住宅が増え、 食事提供までの軽度の支援に対応した住宅の比率が高まり、形態の 選択肢が増える。町村部の場合、住み慣れた地域での居住継続志向 が高いため介護が必要になるまで転居のニーズは低く、地域の現状 に対応していると考えることもできる。しかし実際の居住者の介護 程度は都市規模による差は小さく、必ずしも町村部で中・重度の居 住者が多いわけではなかった。また、転居に起因する要件には防犯・ 災害等の不安もある ${ }^{19)}$ 。住宅の選択肢として、自立度の高い時期の 生活に対応する住宅の整備が望まれる。

空間構成との不適合は、居住者の世帯規模と介護程度の点から指 摘できる。世帯規模については、共用型住戸で構成された住宅での 夫婦世帯の入居が確認でき、同室ニーズに対応し難い状況が示され た。介護程度については、共用型住戸で構成される住宅居住者の 4 割、完備型と共用型住戸で構成される住宅（住戸の大半は共用型） 居住者の 5 割以上が自立・軽度者であった。自立者はもちろん、軽 度者も日常生活はおおむ称自立できる状態注 17) であり、自律的な生 活が期待できる居住者が共用型住戸で生活している実態が示された。 これらの点から、空間構成とくに住戸の住居水準と居住者の生活状 況との間で不適合が起きている可能性が示唆される。

設備の共用化は住戸での生活行動に制限を与え、活動への意欲低 下を招きかねない 20)。また、三浦ら ${ }^{9)}$ は、「住戸面積の緩和規定に 則っても、必ずしも十分な共用部分の面積に至っていない。面積基 準の緩和は要介護者を想定した住戸を増やす」と指摘している。自 律生活の継続と介護予防、夫婦世帯の入居ニーズの観点に立てば、 住戸において基本的な生活行為が可能となる住居水準を備えたうえ

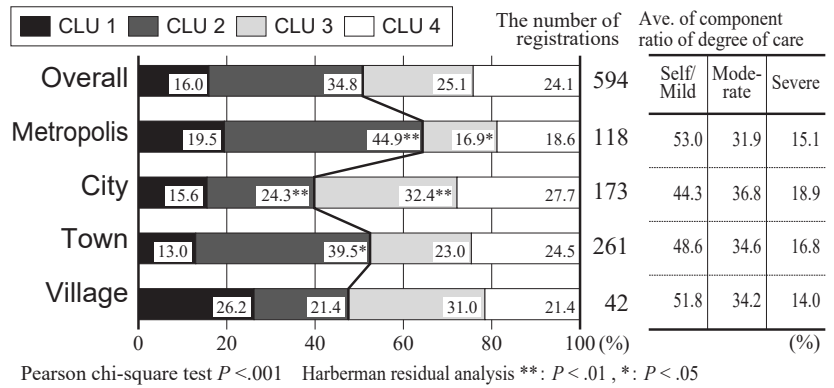

Fig.12 Component ratio of the cluster groups with city size

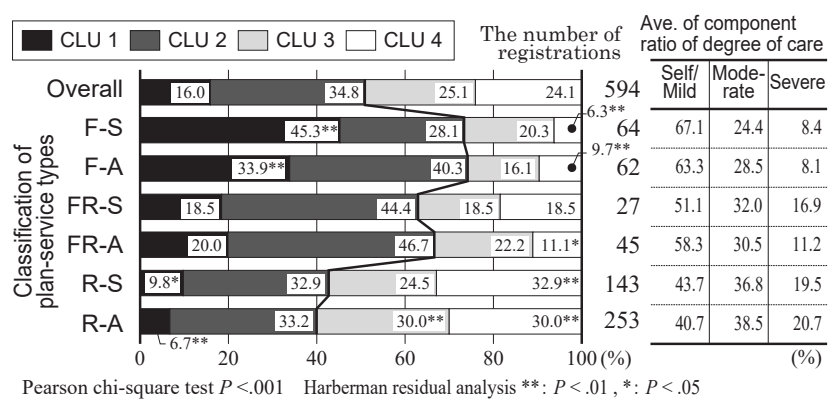

Fig.13 Component ratio of the cluster groups with the floor plan types and the support service types 
で共用設備も含めた空間計画が望まれる。加えて、心身機能が低下 する高齢期は設備部分の必要面積が広くなる。最低居住面積水準を 参照した住戸面積には設備部分も含むので、必然的に日常生活空間 を狭小化させる。トイレやキッチンを除いた「居室」としての面積 基準の見直しが必要ではないだろうか。

一方で、進行する心身機能の低下に対して、住戸における専用設 備の設置や面積の拡大の必要性についての議論がある。この点につ いては、居住者の要介護状態の汎用性を考慮して、いくつかの住居 水淮をもつ住戸をサ高住のなかに設けることで、心身機能の変化に 応じた住み替えが可能な住戸構成で対応できるのではないだろうか。 本論文で触れた FR 住宅がこれに近い空間構成となるが、現状では 設備を備えた完備型住戸は夫婦等の世帯の入居を想定したものと考 えられ、戸数も少ない。現在の居住者の介護程度の構成をみたとき、 完備型と共用型住戸が同数程度の住戸構成が必要であろう。

本論文で明らかにした居住者の要介護状態と空間構成との不適合 は、統計量に基づいた概括的な考察に止まっている。居住者の生活 行動に影響を与える要素は、共用設備の配置や数、提供サービスの 具体的な利用状況など多数あると考えられる。今後、詳細な調查を 実施することで、居住者の生活行動と住居水準との不適合の実態を 明らかにし、建築計画的な知見を得る予定である。

最後に、住居水準の向上は家債のほか維持管理費も含めた経済的 負担を伴う。最低限の住居水準の住戸が主流となっている背景には 居住者の家賃負担能力もある。町村部ではとくに大きく影響してい ると推察される。本論文ではこの点についての研究にまで至ってい ないが、一定の質を担保した住戸整備のためには久くことのできな い課題である。加えて、井上 ${ }^{14)}$ は「(前略) 住宅扶助と市場価格の 連動性が精緻でないなかで、特養の利用対象像に近似している生活 保護受給者を（サ高住で）受け止めることが適切なのかを検討した ほうがよい。」と困窮と住宅保障の視点からも問題提起している。住 宅政策・住宅扶助・介護も含めた生活支援、これらを総合的に検討 したうえでサ高住の制度のあり方を再考する必要がある。

\section{謝辞}

本研究の一部は JSPS 科研費 JP16K00805 の助成を受けたもの です。調査にご協力いただいた事業者様に心より感謝申し上げます。

\section{参考文献}

1) Mariko, S.: Home as a foundation in the Integrated community care, Hiroshi, T. (Ed): The Integrated Community Care System, Ohmsha, Ltd., pp.130-149, 2012.3

園田眞理子: 地域包括ケアの基盤としての住まい, 高橋紘士 編: 地域包括 ケアシステム, オーム社, pp.130-149, 2012.3

2) Ministry of Health, Labour and Welfare, Ministry of Land, Infrastructure, Transport and Tourism: Basic policies on a preparation of the housing on the senior stage, Notification No.3, 2016.8.19 厚生労働省，国土交通省：高齢者の居住の安定の確保に関する基本的な力 針, 厚生労働省・国土交通省告示第 3 号, 2016.8.19

3) Ministry of Land, infrastructure, Transport and Tourism: Present and analysis for the residences for elderly people with service, 2014.3.31 国土交通省：サービス付き高齢者向け住宅の現状と分析 (平成 26 年 3 月末 時点），サービス付き高齢者向け住宅情報提供システム http://www.satsuki-jutaku.jp/doc/system_registration_02.pdf

4) Ministry of Land, infrastructure, Transport and Tourism: The report of the investigative meeting on the state of the preparation for the elderly housing, Press release, 2016.5.24

国土交通省：サ高住整備等のあり方に関する検討会とりまとめ, 報道発表 資料, 2016.5.24

5) Motohiro, S. Yoshihiro, S. and Byung joon, H.: Comparative analysis of living space forming equipment and life support of the elderly housing in urban and rural areas, Summaries of Technical Papers of Annual Meeting, Architectural Institute of Japan, Architectural Planning and Design, pp.37-38, 2015.9 (in Japanese)

三宮基裕, 鈴木義弘, 黄昞峻: 都市規模からみたサービス付き高齢者向け 住宅の空間構成と支援形態, 日本建築学会大会学術講演梗概集, 建築計画, pp.1101-1102, 2015.9

6) Motohiro, S. Yoshihiro, S. and Byung joon, H.: A study of the mismatch in the retirement homes between the life style and the housing environment, AIJ Kyushu Chapter Architectural Research Meeting, No. 55, pp.157-160, 2016.3 (in Japanese)

三宮基裕, 鈴木義弘, 黄昞峻 : サービス付き高齢者向け住宅の想定する入居 者像と空間構成・支援形態の不適合に関する考察, 日本建築学会九州支部 研究報告, 第 55 号, pp.157-160, 2016.3

7) Masataka, N. Mari, K. Kentaro, Y. and Tomoko, S.: A study on the floor plan composition of elderly housing with supportive services from plan analyses, Journal of Architecture and Planning (Transactions of AIJ), Vol. 81, No. 720, pp. 271-279, 2016.2 (in Japanese)

永浜正貴, 絹川麻理, 山口健太郎, 志垣智子: 図面分析から見たサービス付 き高齢者向け住宅の平面構成に関する研究, 日本建築学会計画系論文集, Vol.81 No.720, pp.271-279, 2016.2

8) Kentaro, Y: Architectural planning about the elderly housing with supportive services, Urban housing sciences, No. 93, pp.64-67, 2016.4 山口健太郎：サービス付き高齢者向け住宅の建築計画, 都市住宅学, 第 93 号, pp.64-67, 2016.4

9) Ken, M. Chika, K.: The report on a relaxation of reference area by prefectures about the elderly housing with supportive services and the influence of this, Urban housing sciences, No. 93, pp.68-73, 2016.4 三浦研, 工藤千佳：サービス付き高齢者向け住宅の都道府県等による独自 の面積緩和基準とその影響, 都市住宅学, 第 93 号, pp.68-73, 2016.4

10) Kentaro, Y. Tetsuya, K.: Independent Living of Residents in the Service Housing for the Elderly, Summaries of Technical Papers of Annual Meeting, Architectural Institute of Japan, Architectural Planning and Design, pp.37-38, 2015.9 (in Japanese)

山口健太郎, 金子哲也：サービス付き高齢者向け住宅における生活の自立 に関する事例考察, 日本建築学会大会学術講演梗概集, 建築計画, pp.37-38, 2015.9

11) Kentaro, Y.: A case study of behavioral patterns and living activities in dwelling unit Independent living of residents in the service housing for the elderly Part.2, Summaries of Technical Papers of Annual Meeting, Architectural Institute of Japan, Architectural Planning and Design, pp.961-962, 2016.8 (in Japanese)

山口健太郎：生活展開と住戸内での住まい方に関する事例考察 サービス 付き高齢者向け住宅における生活の自立に関する研究 その 2 , 日本建築学 会大会学術講演梗概集, 建築計画, pp.961-962, 2016.8

12) Masayuki, Y. Kentaro, Y. and Mitsuo, T.: A study of the process of moving in the housing for the elderly and on the change of life in residents before and after, Journal of Architecture and Planning (Transactions of AIJ), Vol. 79, No. 695, pp. 11-20, 2014.1 (in Japanese) 山田雅之, 山口健太郎, 高田光雄: 高齢者向け住宅一の入居経緯と入居前 後における生活の変化に関する研究, 日本建築学会計画系論文集, Vol.79 No.695, pp.11-20, 2014.1

13) Eiji, S. Yukiko, I. and Kyoko, I.: A fundamental study towards establishing a guiding principle on developing elderly housing with life support service, Journal of Architecture and Planning (Transactions of 
AIJ), Vol. 76, No. 667, pp. 1527-1535, 2011.9 (in Japanese)

佐藤栄治，井上由起子，生田京子：サービス付き高齢者向け住宅の整備方 針確立に向けた基礎的研究，日本建築学会計画系論文集，Vol.76 No.667, pp.1527-1535, 2011.9

14) Yukiko, I.: Problem on the elderly housing systems about "Sumai" on the elderly generation, Urban housing sciences, No. 93, pp.27-31, 2016.4 井上由起子：高齢期の「住まい」をめぐる制度上の課題，都市住宅学，第 93 号, pp.27-31, 2016.4

15) Byung joon, H. Yoshihiro, S.: Issues of planning on daily life performance in group home: Effectiveness on the living conditions of private room in the group home for dementia Part 2, Journal of Architecture and Planning (Transactions of AIJ), Vol. 76, No. 664, pp.1063-1071,2011.6 (in Japanese)

黄昞峻, 鈴木義弘：グループホームにおける居住者の生活行為の分析と課 題について 認知症高齢者グループホームでの生活に居室水準が与える影 響に関する研究第 2 報, 日本建築学会計画系論文集, Vol.76 No.664, pp.1063-1071, 2011.6

16) Nobuhiro, M. Yoshihiro, S.: Consideration on Planning Concepts of "Elderly Housing for Rent" from The View of Classification, AIJ Kyushu Chapter Architectural Research Meeting, No. 46, pp.109-112, 2007.3 (in Japanese)

松川修啓，鈴木義弘：高優賃及び高専賃の類型的把握と計画課題について， 日本建築学会九州支部研究報告, 第 46 号, pp.109-112, 2007.3

17) Architectural Institute of Japan (Ed.): Handbook of Environmental Design [Welfare \& Medical], Maruzen Publishing Co., Ltd., p.31, 2002.9 日本建築学会 編: 建築設計資料集成 [福祉 - 医療], 丸善, p.31, 2002.9

18) Midori, N. (Editor): Theories on Barrier Free Environment, 2nd ed., Ishiyaku Publishers, Inc., p.220, 1997.5

野村みどり 編：バリアフリーの生活環境論第 2 版，医歯薬出版，p.220， 1997.5

19) Cabinet Office, Government of Japan: Annual Report on the Aging Society 2015 , pp.56-58, 2015.7

内閣府：平成 27 年版高齢社会白書, pp. $56-58,2015.7$

20) Motohiro, S. Yoshihiro, S. and Byung joon, H.: The case study of the lifestyle in the elderly housing, Journal of Kyushu University of Health and Welfare, No. 16, pp.23-32, 2015.3 (in Japanese)

三宮基裕，鈴木義弘，黄昞峻：サービス付き高齢者向け住宅居住者の住ま い方に関する事例考察, 九州保健福祉大学研究紀要, 第 16 号, pp.23-32, 2015.3

21) Cabinet Office, Government of Japan: The report on According to Survey on Attitude toward Dwelling and living environment for the elderly, pp.70-75, 2011.3

内閣府：高齢者の住宅と生活環境に関する意識調査結果, pp.70-75, 2011.3

22 ) Ministry of Land, infrastructure, Transport and Tourism: The formulation basic plans for housing (National plans), 2016.3.18 国土交通省：住生活基本計画（全国計画）, 2016.3 .18 閣議決定

\section{注}

注 1）高齢者向け住宅は明確な定義がなされていない。本研究では, 医療・ 福祉専門職が常駐または連携・協力などにより入居者に支援, 援助, 介護 サービスを提供する賃貸住宅および老人ホーム（介護保険 3 施設を除く） と広く解釈している，具体的にはシルバーハウジング，高齢者向け優良顀 貸住宅，ケアハウス，有料老人ホームなどである.

注 2） 2011 年の高齢者の居住の安定確保に関する法律の改正によって, 高齢 者円滑入居賃貸住宅および高齢者専用賃貸住宅の登録，高齢者向け優良顀 貸住宅の認定が廃止され，新たにサービス付き高齢者向け住宅の登録制度 が始まった．有料老人ホームの登録も可能となっている.

注 3) 平成 22 年度の内閣府の調查 ${ }^{21)}$ によると, 子どもとの将来同居の意向は 平成 13 年度 $46.8 \%$ から $37.5 \%$ まで減少し, 逆に将来別居は $17.9 \%$ から $26.3 \%$ に増加している．また，虚弱化したときの居住形態として「介護が
受けられる有料老人ホームなどの施設」が $3.0 \%$ から $9.7 \%$ まで増加し，そ れと同程度の比率で「ケア付き住宅」が挙がっている。

注 4）本論文では住居水準として住戸の面積と、住戸に設置されている設備 の種類を評価した。

注 5）本論文では，介護保険法上の「要介護状態」に加えて，自立および同 法定義の「要支援状態」を総称して「要介護状態」の用語を用いる.

注 6) システムに登録されている情報には各住宅共通項目と自由記述による 項目がある．本論文では共通項目情報を極力用いることとし，入力者の裁 量による影響に配慮した。

注 7) 1 回目の回答数は 145 カ所で統計上必要な標本数が得られなかったた め, 追加調查を実施した。母集団 3,414 力所に対して信頼度 $95 \%$ （信頼度 係数 1.960), 誤差率土 $5 \%$ の場合では 346 力所以上の標本数が必要であり, 本調査の回答数 617 カ所は $95 \%$ 以上の信頼度が得られていると推定できる. 注 8）合併による広域化により行政区分上の人口規模とサ高住所在地周辺の 人口規模は異なると考えられる。本論文では地方分権一括法が施行された 2000 年当時の都市境域を茾高住所在地に当てはめ, 調査時点で最新の平成 22 年（2010）国勢調査の人口等基本集計に記される境域年次（2000）の 人口情報を適用して、サ高住所在地の都市規模を区分した.

注 9）面積は最低居住面積水準および都市居住型誘導居住面積水準を目安と

し，設備はキッチンと浴室が備えられているかどうかを基準とした。

注 10）分析に利用した情報提供システムのデータは，共用設備については統 一された情報ではなく自由記述によるものであったため,「居間（リビン グ)」「食堂 (ダイニング)」「台所 (キッチン)」と記載されているものはそ のまま採用し, 談話室, デイルーム, 喫茶室などはその名称から用途を主 観的に判断して $\mathrm{L} \cdot \mathrm{D} \cdot \mathrm{K}$ に含めた.

注 11）本論文では，最もプリミティブな空間構成を把握するために，住戸内 設備の設置タイプ (2.3.1 の住戸タイプの分類での完備型・共用型) と共用 LDK の有無の組合せを空間構成の分類軸として採用した。より厳密な空間 構成の理解のためには共用設備の数や設置場所についても考慮する必要が あるが，この点について本論文では分析に至っていない.

注 12）サービスの提供形態のうち,「自ら」「委託」「自らと委託の併用」を 『提供あり』とし，「提供しない」を『提供なし』とした.

注 13）高齢期に必要なサービスには心身状況に応じて「支援」「援助」「介護」

「看護」「医療」「終末介護」の段階があり, 状態変化とともに逐次付加さ れると考えられる。松川らは，ライフステージにおける自立期から臥床期 において必要となる生活支援を, 基本的支援, 家事支援, 個人的支援に分 け，無生活支援型（生活支援を一切おこなっていない），セルフケア型（基 礎的な生きがい対策，相談などの支援までおこなう)，レジデンシャルケア 型（家庭機能の代替的な支援までおこなう），パーソナルケア型（介助等パ ーソナルな支援までおこなう）に類型化している。サ高住の提供サービス では食事提供の有無が特徴的であったため, 家事支援とは分けて分類した。

注 14）国土交通省の住生活基本計画 ${ }^{22)}$ の居住面積水準を参考に, 住戸面積を

$\left\lceil 18 \mathrm{~m}^{2}\right.$ 以上 : $18 \mathrm{~m}^{2}$ 以上 $25 \mathrm{~m}^{2}$ 未満」 $\left\lceil 25 \mathrm{~m}^{2}\right.$ 以上 : $25 \mathrm{~m}^{2}$ 以上 $30 \mathrm{~m}^{2}$ 未満」「30 $\mathrm{m}^{2}$ 以上 : $30 \mathrm{~m}^{2}$ 以上 $40 \mathrm{~m}^{2}$ 未満」「 $40 \mathrm{~m}^{2}$ 以上」に区分した. 複数の面積階級 が存在する住宅については面積階級が何種類あるか整理し，3 種類以上あ る場合は階級度数が多い順に上位 2 つの面積階級を取り上げた。

注 15）アンケートでは要介護度を目安に「自立」「軽度：要支援 1 要介護 1 程度」「中度 : 要介護 $2 \sim 3$ 程度」「重度 : 要介護 $4 \sim 5$ 程度」「その他」 の選択肢を設定した。「その他」に付記された自由記述回答（例：トイレが 自立の方, 介護認定を受けている方など）は記述内容を解釈し, 適宜, 厚 生労働省が示す要介護状態区分別の状態像を参考にして再分類した.

注 16）大規模ケースの場合一般的には非階層的方法が用いられるが，本論文 では分類したクラスターを用いて個別のケースについて分析するため，類 似性の高いケースから結合する階層的方法を採用した。分析対象は，居住 者の要介護度が無回答であった 23 力所を除く, 594 力所である.

注 17）平均的な状態の目安として「要介護度別の状態区分」がある。これに よると要介護 1 は「身だしなみや居室の掃除など身の回りの世話に何らか の介助を必要とする」「移動動作に何らかの支えを必要とする」「排泄や食 事はほとんど自分ひとりでできる」とあり, 福祉用具活用やわずかな生活 支援によって日常生活はある程度自立可能と判断した。 


\title{
THE CONSIDERATIONS OF THE MISMATCH BETWEEN THE QUALITY LEVEL OF THE DWELLING UNIT AND THE HEALTH CONDITION OF RESIDENTS IN THE ELDERLY HOUSING WITH SUPPORTIVE SERVICES
}

\author{
Motohiro SANNOMIYA ${ }^{* 1}$, Byung joon HWANG ${ }^{* 2}$ and Yoshihiro SUZUKI ${ }^{* 3}$ \\ ${ }^{* 1}$ Assoc. Prof., Kyushu Univ. of Health and Welfare, M.Eng. \\ ${ }^{* 2}$ Part-time lecturer, faculty of Eng., Oita Univ., Dr.Eng. \\ ${ }^{*}$ Prof., faculty of Eng., Oita Univ., Ph.D.
}

Introduction

Japanese government is aiming to establish the community care system for it that the elderly can continue to live in their own community where they have lived long. The elderly housing with supportive services (below is called the housing) institutionalized in 2011 is regarded as the one of central pillar of this system. The number of the housings has been build more than six thousand from five years ago, and it has been increasing rapidly, meanwhile it is indicated problems of quality of the dwelling units. The purpose of this study is to obtain knowledge about an improvement in quality of the living environment in the housing by clarify mismatches in the housing between the health condition of residents and the quality level of the dwelling units.

Method

At first, we gathered data of 3,414 about the building from the information providing system on WEB site. At next, we conducted questionnaire survey about the resident image and the health condition of residents etc. targeting the management bodies of 3,414 housing, and 617 questionnaires were returned. (Table1)

Result

Many the housings have been built in the city where more than 10,000 people lives, there are only $5.1 \%$ of overall in the countryside. (Table2) The dwelling unit equipped with only toilet account for 56.2\%. Especially in the countryside, there are as many as $82.2 \%$ this type. (Fig.3) There are three types to the floor plan of the housing, Shared-type account for 69.0\%. (Fig.6) The support services divide into four types; major service types are MO and PC. (Fig.7) We classified into six classes by combination of the floor types and the support service types, analyzed the result of the questionnaire. (Fig.8) R-S and R-A tended to expect only single-person move into the housing in comparison with F-S and F-A. (Fig.9) F-S and F-A has expected residents who are self-support or need to mild care move into the housing, but others, R-S and R-A has expected residents who are moderate or severe care too. (Table9) We conducted a cluster analysis about the care degree for residents. We could get four characteristics clusters.

(Fig.11) While CLU1 or CLU2 are account for about $75 \%$ of F-S and F-A, CLU3 or CLU4 are account for about $60 \%$ of R-S and R-A. However, about $40 \%$ of residents who live in R-S and R-A are self-support or mild care. (Fig.13)

Conclusion

Most of the housing have poor facilities and small floor areas in the dwelling unit. Therefore, the living environment is lower quality. Especially the countryside tends to its. We consider that the primary reasons for the lower quality are what the management bodies has expected residents of need to care and the single-person move into the housing. They may be imaging that shared type is adequate areas and facilities for such residents. Actually, about $50 \%$ of residents are self-support or need to mild care level. Therefore, there are mismatch the floor plan and resident life in the housing of the shared type. There are little the number of the housing in the countryside. Furthermore, there are problems of quality of living environment. We conclude that standards of the housing should be considered about the quality of living environment. The housing will need to be improved that are able to match for the lifestyles from self-support to sever care level. 